\title{
Experimental evaluation on the structural behavior of truss shear connectors in composite steel-concrete beams
}

\section{Avaliação experimental sobre o comportamento estrutural de conectores de cisalhamento treliçados em vigas mistas de aço e concreto}
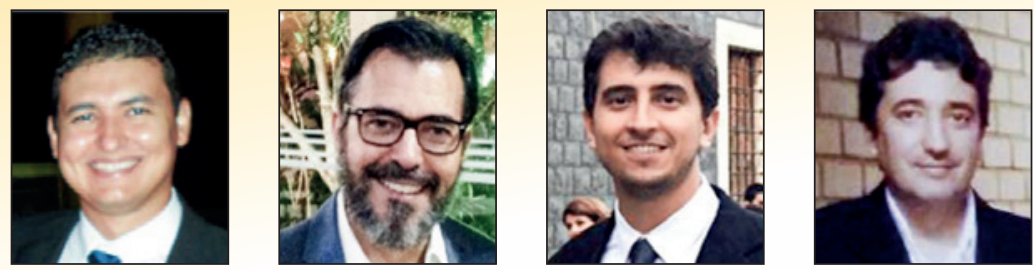

\author{
W. C. S. BARBOSA \\ wallcsb@gmail.com \\ https://orcid.org/0000-0002-0516-0914 \\ L. M. BEZERRA b \\ Imbz@unb.br \\ https://orcid.org/0000-0002-5789-9649 \\ L. CHATER b \\ latifchater@gmail.com \\ https://orcid.org/0000-0002-5086-6852 \\ O. R. O. CAVALCANTE \\ otaviorc@hotmail.com \\ https://orcid.org/0000-0001-8565-297X
}

\begin{abstract}
The composite structures have great advantages in terms of structural and constructive aspects, with the shear connectors being decisive for obtaining the interaction between the structural elements and for the distribution of the stresses in the structure, taking advantage of the potentiality of each constituent material of the composite structure (steel and concrete). This work, through experimental studies, presents the development of a shear connector (Truss connector) proposed for use in a concrete-steel composite beam. The proposed connector is easy to implement and can serve as a viable alternative to the use of stud or $U$ connectors. It was idealized a connector geometry that would provide low production cost, ease of execution, higher values of resistant load, efficiency as regards the relative sliding resistance between the metal profile and the concrete slab, as well as the efficiency regarding the resistance to the spacing of the slabs in relation to the metal profile (uplift). In order to evaluate the behavior of Truss connectors, 6 experimental models were constructed for push-out tests, 3 with $12.5 \mathrm{~mm}$ diameter Truss connectors and 3 with $19.0 \mathrm{~mm}$ diameter stud bolt connectors. The behavior of the models was investigated with respect to the loads of rupture, the transversal displacements between the concrete slabs and the relative vertical slide between the reinforced concrete slabs and the metallic profiles of the models. The results of the experimental analyzes provided an overview of the operation of the Truss and stud bolt connectors, with significant results that showed advantages of the Truss connector in relation to the stud connector considering the parameters analyzed in this work.
\end{abstract}

Keywords: composite structures, steel, concrete, shear connectors.

\section{Resumo}

As estruturas mistas apresentam grandes vantagens quanto a aspectos estruturais e construtivos, sendo os conectores de cisalhamento determinantes para a obtenção da interação entre os elementos estruturais e para a distribuição dos esforços na estrutura, aproveitando-se de forma efetiva da potencialidade de cada material constituinte da estrutura mista (aço e concreto). Este trabalho, por meio de estudos experimentais, apresenta o desenvolvimento de um conector de cisalhamento (conector Treliçado) proposto para uso em viga mista de aço e concreto. O conector proposto é de fácil execução e pode servir como alternativa viável ao uso dos conectores stud ou U. Foi idealizada uma geometria para o conector que propiciasse baixo custo de produção, facilidade de execução, maiores valores de carga resistente, eficiência quanto a resistência aos deslizamentos relativos entre o perfil metálico e a laje de concreto, bem como a eficiência quanto a resistência ao afastamento das lajes em relação ao perfil metálico (uplift). A fim de avaliar o comportamento dos conectores Treliçados foram construídos 6 modelos experimentais, para ensaios de push-out, $3 \mathrm{com}$ conectores Treliçados de $12,5 \mathrm{~mm}$ de diâmetro e $3 \mathrm{com}$ conectores stud bolt de 19,0 mm de diâmetro. Investigou-se o comportamento dos modelos quanto às cargas de ruptura, os afastamentos transversais entre as lajes de concreto armado (uplift) e os deslizamentos verticais relativos entre as lajes de concreto armado e os perfis metálicos dos modelos. Os resultados das análises experimentais proporcionaram uma visão global do funcionamento dos conectores Treliçados e stud bolt, com resultados significativos que evidenciaram vantagens do conector Treliçado em relação ao conector stud considerando os parâmetros analisados neste trabalho.

Palavras-chave: estruturas mistas, aço, concreto, conectores de cisalhamento.

Universidade Federal do Piauí, Departamento de Estruturas, Teresina, PI, Brasil;

Universidade de Brasilia Departamento de Engenharia Civil e Ambiental, Brasilia, DF Brasil;

Universidade Federal do Ceará: Departamento de Engenharia Civil, Fortaleza, CE, Brasil.

Received: 03 Oct 2016 • Accepted: 16 Mar 2018 • Available Online:

बrew This is an open-access article distributed under the terms of the Creative Commons Attribution License 


\section{Introduction}

Technical, scientific, and economic development has brought forth a great variety of structural systems, amongst them steel-concrete composite structures, which prove efficient both structurally and in regards to the ease of construction. Structurally, the resistance properties of the composite structure's constituent materials are better employed (Cavalcante, 2010), generating lighter and more optimized structures. For the slab and the steel profile to act as a composite structure, a connection between the concrete and the steel is needed. To that end, steel elements called shear connectors are used, embedded in the concrete and connected to the steel profile.

The choice of the type and dimensions of the connectors is of great importance, for it is through them that one determines the degree of interaction and the manner in which the stresses are distributed between the materials (steel and concrete). Experimental and numerical studies are important means to gaining a better understanding of the behavior of these connectors and the way composite steel-concrete structures work. The most widely used shear connector for composite beams is the stud bolt, with design criteria specified in the Brazilian Standard ABNT NBR 8800:2008 [2], which also presents the design methodology for the "U" type connectors for composite steel and concrete structures. Over the years, many shear connectors have been developed with the intention of improving the interaction between steel and concrete for composite structures.

Studies on shear connectors began in 1933 in Switzerland, at the Swiss Federal Institute for Testing Materials, through a partnership with the System Alpha project. The analyzed connector was formed by a round bar in a spiral shape, named the Spiral Connector (Chaves, 2009) [3]. In Brazil some alternate connectors have been studied, such as the Crestbond type connector, derived from the Perforbond type, and studied experimentally by Verissimo (2007) [4] and the "V" type connector, developed and assessed experimentally by Cavalcante (2010) [1].
Recent research has shown efforts by the scientific community directed towards understanding the behavior of non-welded connectors, as presented in the works of Rehman et al. (2015) [5], Dai et al. (2015) [6] and Pathirana et al. (2015) [7]. Other recent works have also addressed the study of alternative connectors, developed with the use of materials well known to the construction industry, as may be observed in the research conducted by Barbosa (2016) [8]. He used steel reinforcement bars for reinforced concrete of the CA-50 variety for the manufacturing of new types of shear connectors. Figure 1 presents the shear connectors developed through the research works of Cavalcante (2010) [1], Veríssimo (2007) [4], Rehman et al. (2016) [5] and Dai et al. (2015) [6].

\section{Materials and experimental program}

For the evaluation of the behavior of the shear connectors developed in this work, push-out tests were carried out, in accordance with the European Standard EN 1994-1:2004 - Eurocode 4 (hereafter referred to simply as Eurocode 4)[9].

In the experimental direct shear tests (push-out tests) the following parameters were monitored: (a) the relative vertical displacement

\section{Table 1}

Results of concrete compressive strength tests (ABNT NBR 5739:2007 [10])

\begin{tabular}{cccc}
\hline \multicolumn{4}{c}{ Compressive strength (fcj) } \\
\hline $\begin{array}{c}\text { Place of } \\
\text { testing }\end{array}$ & $\begin{array}{c}\text { Age } \\
\text { (days) }\end{array}$ & $\begin{array}{c}\text { Individual } \\
\text { results } \\
\text { (MPa) }\end{array}$ & $\begin{array}{c}\text { Average } \\
\text { (MPa) }\end{array}$ \\
\hline University of Brasília & 28 & 33.6 & \\
- material testing & 28 & 34.2 & 34.0 \\
laboratory (LEM/UnB) & 28 & 34.8 & \\
& 28 & 33.4 & \\
\hline
\end{tabular}

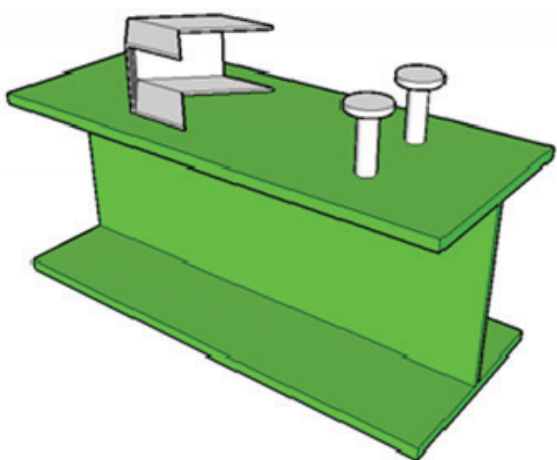

(a)

"V" connector evaluated by Cavalcante (2010) [1]

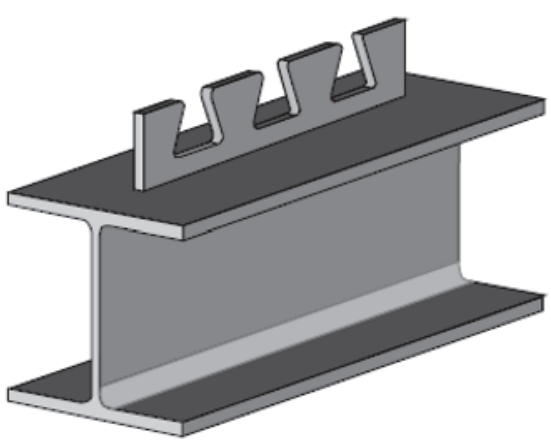

(b)

Crestbond connector evaluated by Veríssimo (2007) [4]

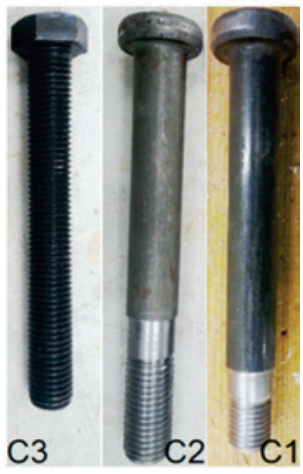

(c)

Non-welded connectors evaluated

by Rehman et al.

(2016) [5] e Dai et al. (2015) [6]

Figure 1

Some alternate shear connectors experimentally evaluated 
Table 2

Results of concrete elasticity module test (ABNT NBR 8522:2008[11])

\begin{tabular}{cccc}
\hline $\begin{array}{c}\text { Place of } \\
\text { testing }\end{array}$ & $\begin{array}{c}\text { Age } \\
\text { (days) }\end{array}$ & $\begin{array}{c}\text { Individual } \\
\text { results } \\
\text { (GPa) }\end{array}$ & $\begin{array}{c}\text { Average } \\
\text { (GPa) }\end{array}$ \\
\hline University of Brasília & 28 & 26.4 & \\
- Material testing & 28 & 26.8 & 26.0 \\
laboratory (LEM/UnB) & 28 & 24.8 & \\
\hline
\end{tabular}

\section{Table 3}

Mechanical properties of the steel bars used in the specimens (ABNT NBR 6892:2013 [12] and ABNT NBR 7480:2007 [13])

\begin{tabular}{ccccc}
\hline $\begin{array}{c}\varnothing \\
(\mathbf{m m})\end{array}$ & $\begin{array}{c}\mathbf{f}_{\mathrm{ss}} \\
(\mathbf{M P a})\end{array}$ & $\begin{array}{c}\varepsilon_{\mathrm{ys}} \\
(\% \circ)\end{array}$ & $\begin{array}{c}\mathbf{f}_{\mathrm{u}} \\
(\mathbf{M P a})\end{array}$ & $\begin{array}{c}\mathbf{E}_{\mathrm{s}} \\
(\mathbf{G P a})\end{array}$ \\
\hline 10.0 & 591.6 & 2.83 & 663.2 & 198.4 \\
12.5 & 595.3 & 3.07 & 716.6 & 195.3 \\
16.0 & 558.3 & 2.91 & 700.6 & 192.0 \\
\hline
\end{tabular}

(sliding) between the steel profile and the concrete slabs of the models, (b) the applied loads, and (c) the distance between the two slabs (uplift). Tests for the characterization of the materials employed in the experimental models were also conducted, as may be observed in Tables 1, 2 and 3.

The shear connector proposed in this research was tested through experimental push-out tests carried out at the University of Brasilia (UnB).

\subsection{Conceptualization of the truss shear connector}

The shear connector proposed in this research (truss-type shear connector or Truss Connector) is made of a steel reinforcement bar for reinforced concrete, CA-50, bent in the shape that forms a right triangle when welded to the beam flange - see Figure 2. The two small pieces of $35 \mathrm{~mm}$ are for welding it onto the flange.
The Truss Connectors discussed in this work were idealized with the aim of obtaining a viable alternative to the stud bolt and the "U" connectors, specified by the Brazilian Code ABNT NBR 8800:2008. The potential of this innovative Truss Connector lies in: (a) its practicality in the building process, (b) the high availability of steel rebars (CA-50), (c) its good mechanical strength, and (d) the fact of its meeting the sliding and uplifting (distancing between slab and steel profile) parameters defined in Eurocode 4 [9].

The goal was to obtain a connector with a behavior analogous to that of the stud bolt specified in the Brazilian Standard ABNT NBR 8800:2008 [2], as an alternative for the design of steel and concrete composite structures. For the Truss Connector, the vertical portion (small leg in Figure 2), in its geometrical disposition, is placed where the stud bolt would be. The longer leg of the connector should be positioned so that it is under tension when the composite beam deforms. Stud bolts with a $19.0 \mathrm{~mm}$ diameter were utilized and both types of connectors, the Truss Connector and the Stud, were built with a $130 \mathrm{~mm}$ height.

For the Truss Connectors, $40 \mathrm{~mm}$ long pieces of rebar were welded to the upper part of each connector to help prevent uplift (separation between slabs and steel profiles in the experimental models), similarly to what the 'head' of the stud bolt does. The connection of the connector with the steel profile was done through fillet welding along the contact of the curved region of the bar with the flange of the steel profile, on the anterior and posterior horizontal parts of the connector, parallel to the axis of the steel profile according to the prescriptions of Table 6 of the Brazilian Standard ABNT NBR 8800:2008 [2]. Eight connectors were placed for each experimental specimen, with each connector welded separately.

\subsection{Experimental push-out tests}

The experimental program consisted of push-out tests carried out on specimens made up of two steel reinforced concrete slabs, with fcj of $34 \mathrm{MPa}$ (as in Table 1), and an ASTM A 57250 degree steel profile, to which eight shear connectors were welded.

Six models were tested in accordance with Eurocode 4 [9]. In this work, the behavior of Truss and Stud Bolt Connectors will be analyzed through

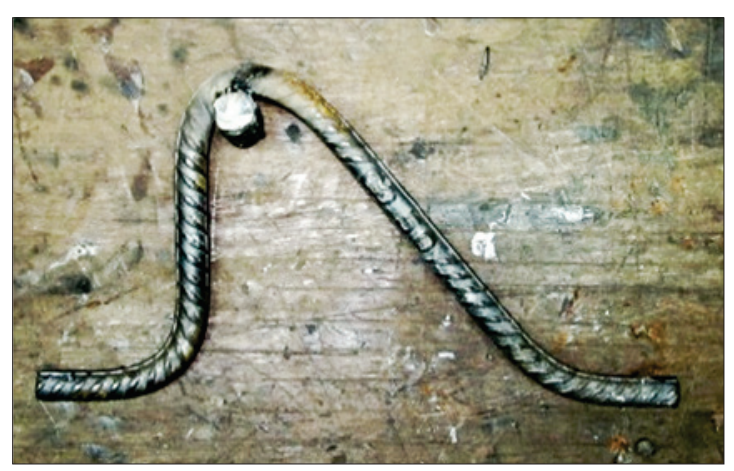

(a)

Truss connector $-\varnothing 12.5 \mathrm{~mm}$

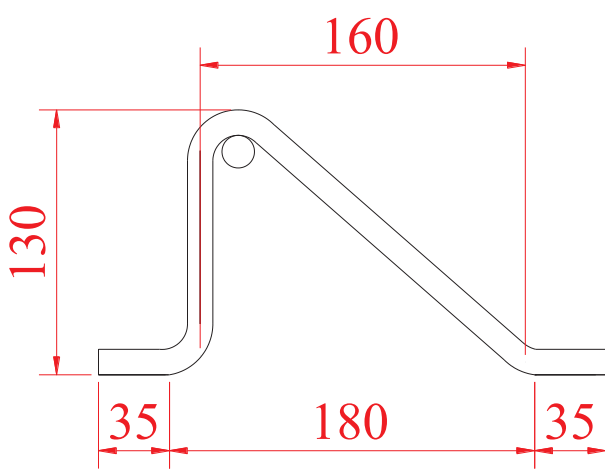

(b)

Truss connector (dimensions in millimeters)

Figure 2

Proposed shear conector in details 
the relationship between the applied loads and the measured vertical displacement (slip) between the steel profile and the slabs and the uplift. Additionally, the maximum strength capacities associated with the Truss and Stud Bolt connectors used in this research were measured.

\subsubsection{Experimental specimens}

Three experimental specimens were built with Truss Connectors and three with Stud Bolt Connectors. For all specimens, the steel profile employed was a W250x73, equivalent to the HEB 260 profile indicated by Eurocode 4 [9], as shown in Figure 3.

Table 4 presents the nomenclature and other details of the specimens analyzed in this work.

All specimens which constitute this experimental program contain reinforcement bars of the CA-50 specification with a $10.0 \mathrm{~mm}$ diameter. Figure 4 details the steel reinforcement utilized for the experimental specimens evaluated.

Figure 5 shows details of the dimensions of the models and the

\section{Measures Und. \\ $b_{\mathrm{f}}=254$ \\ $\mathrm{d}=253$ \\ $\mathrm{h}=225$ \\ $\mathrm{e}_{\mathrm{c}}=14,2$ \\ $\mathrm{t}_{\mathrm{w}}=8,6$ \\ $\mathrm{mm}$ \\ $\mathrm{mm}$ \\ $\mathrm{mm}$ \\ $\mathrm{mm}$}

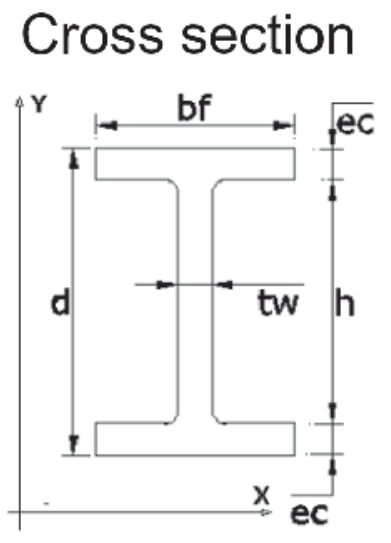

(a)

\section{Figure 3}

W 250x73 steel profile employed for all push-out tests
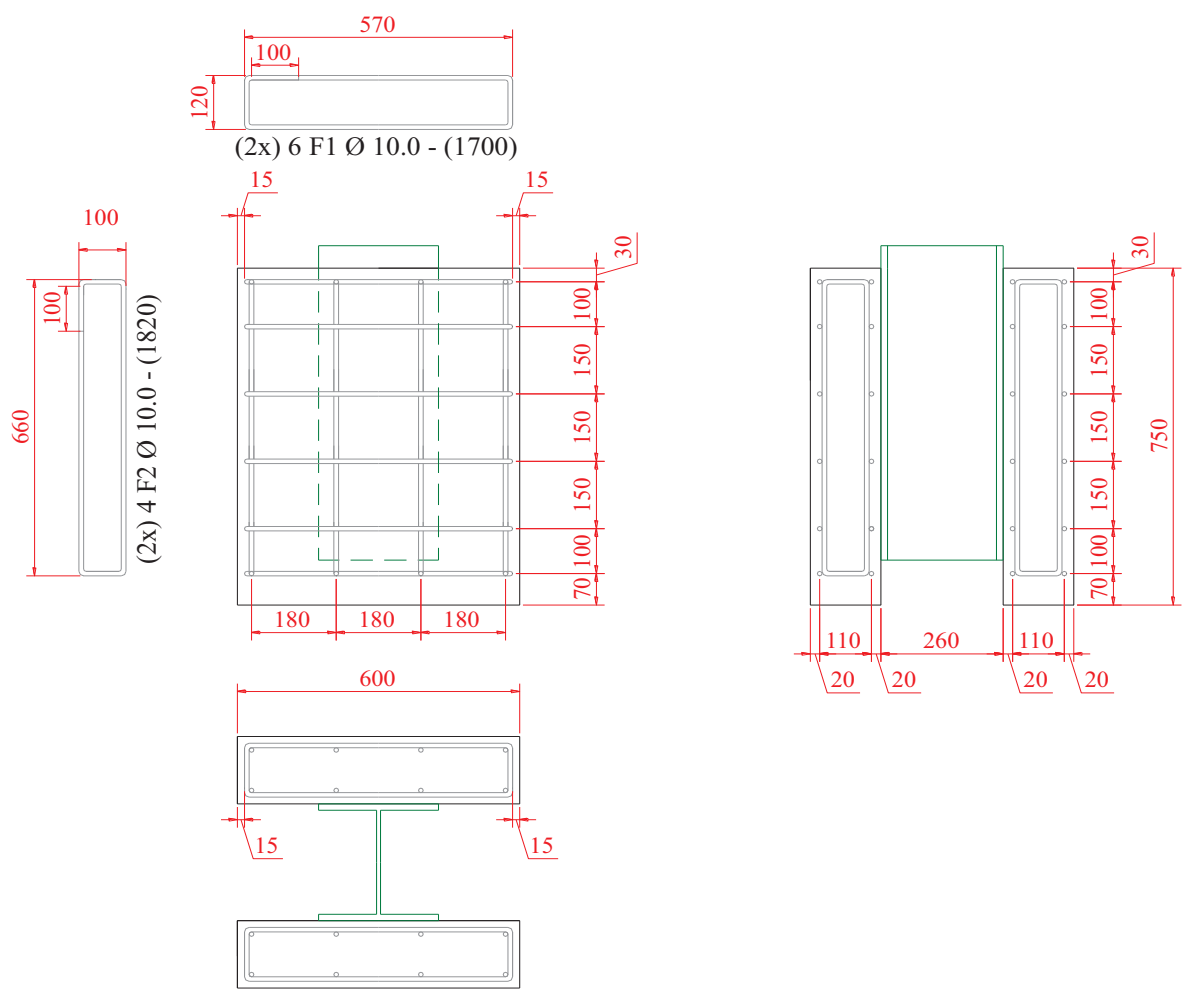

(a)

Design of the reinforcement steel bars

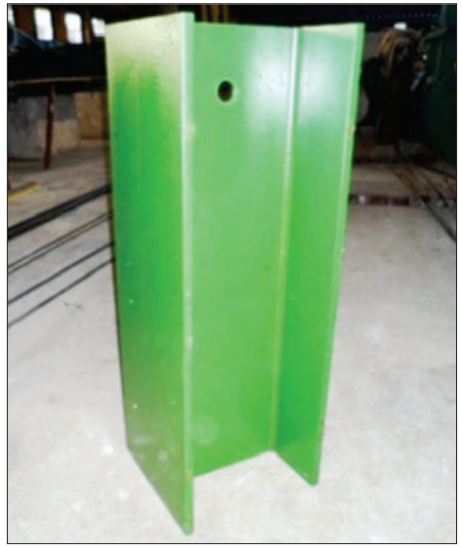

(b)

Steel profile used in the specimens

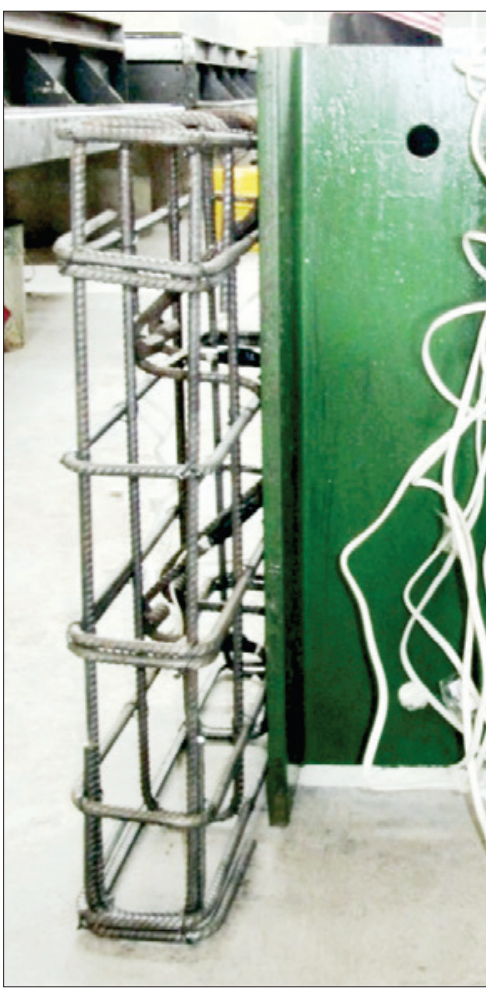

(b)

Details of the steel reinforcement

Figure 4

Experimental specimen slab reinforcement steel bars 
Table 4

Push-out test summary

\begin{tabular}{ccccc}
\hline Type of specimens & $\begin{array}{c}\text { Names of } \\
\text { the specimens }\end{array}$ & Quantity of specimens & Type of connector & Diameter $(\varphi)$ \\
\hline S & S19 & 3 & Stud Bolt & $19.0 \mathrm{~mm}$ \\
R & R12.5 & 3 & $\begin{array}{c}\text { TR - Rectangular } \\
\text { triangle truss }\end{array}$ & $12.5 \mathrm{~mm}$ \\
\hline
\end{tabular}
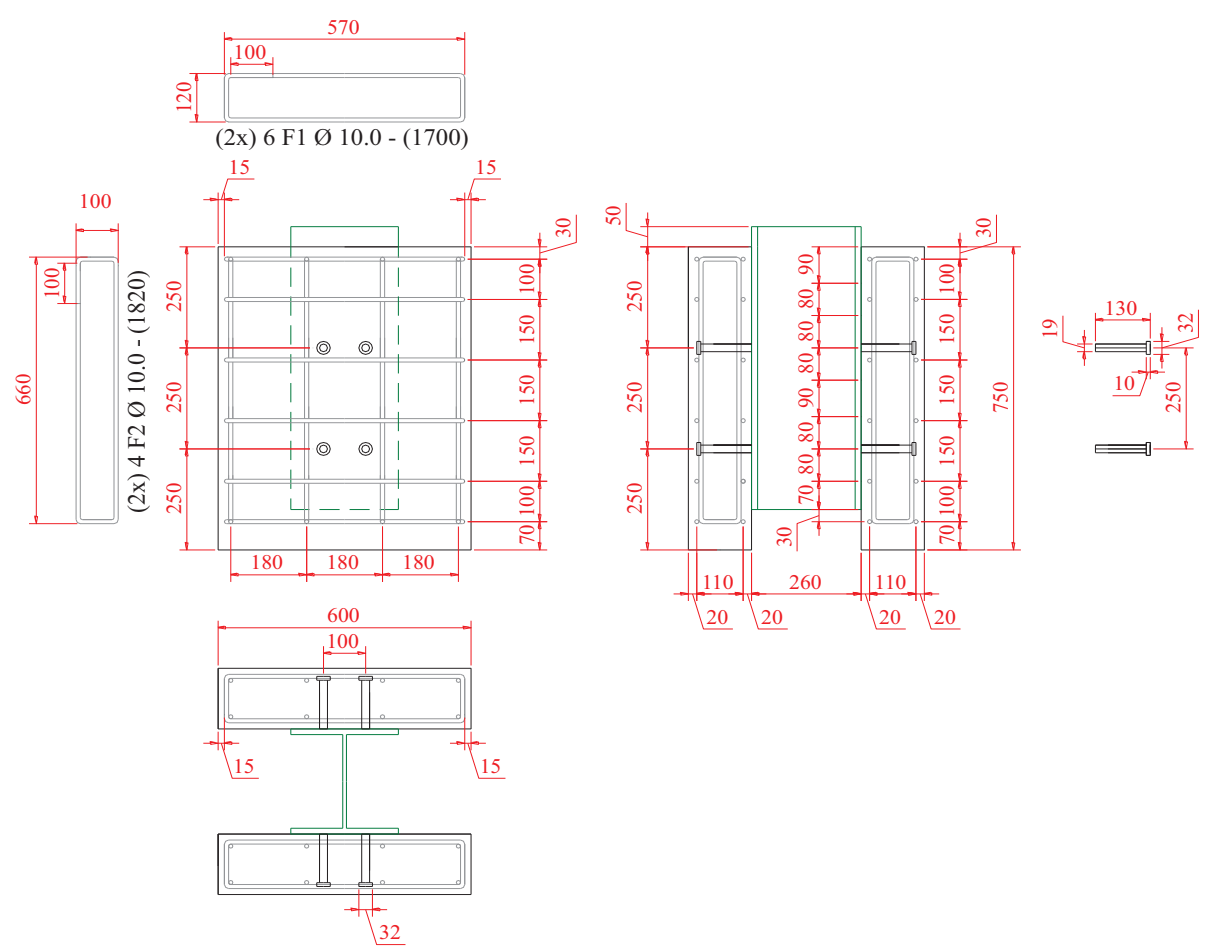

(a)

Specimen details for the $S$ type connectors (stud bolt)
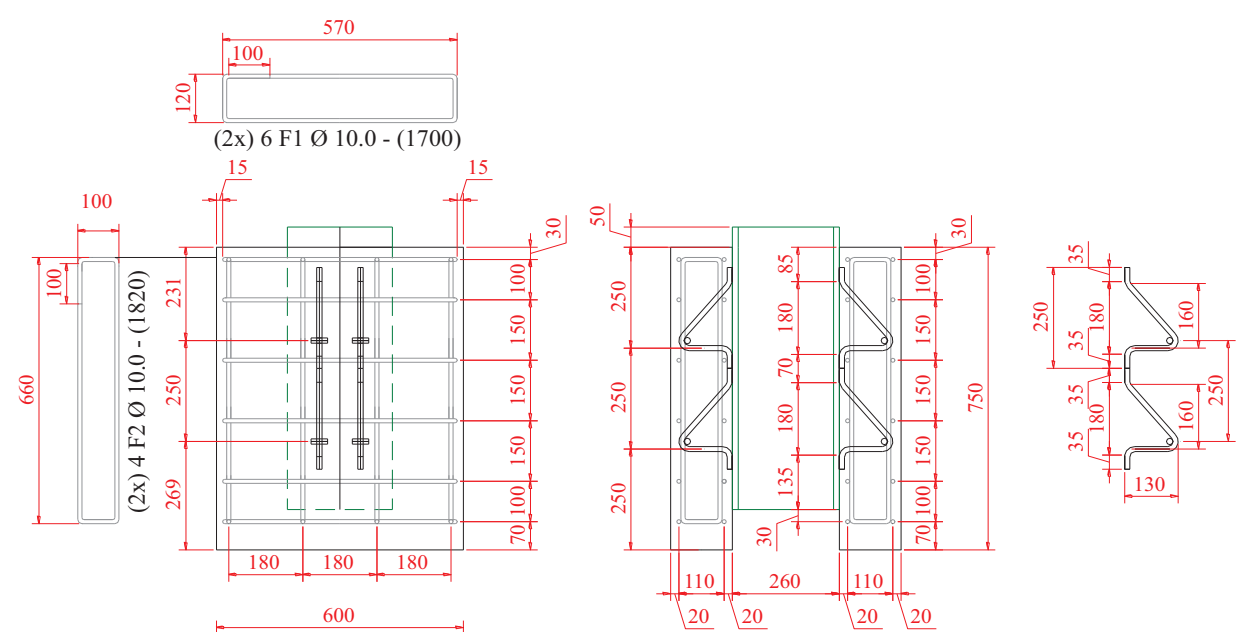

(b)

Specimen details for the TR shear connectors

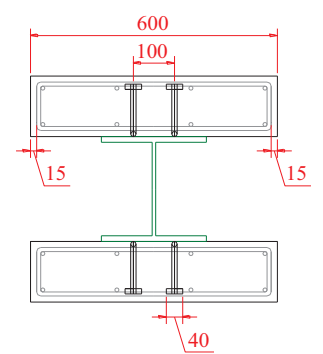

\section{Figure 5}

Positioning of shear connectors and steel reinforcement bars in concrete slabs of specimens (dimensions in milimeters) 


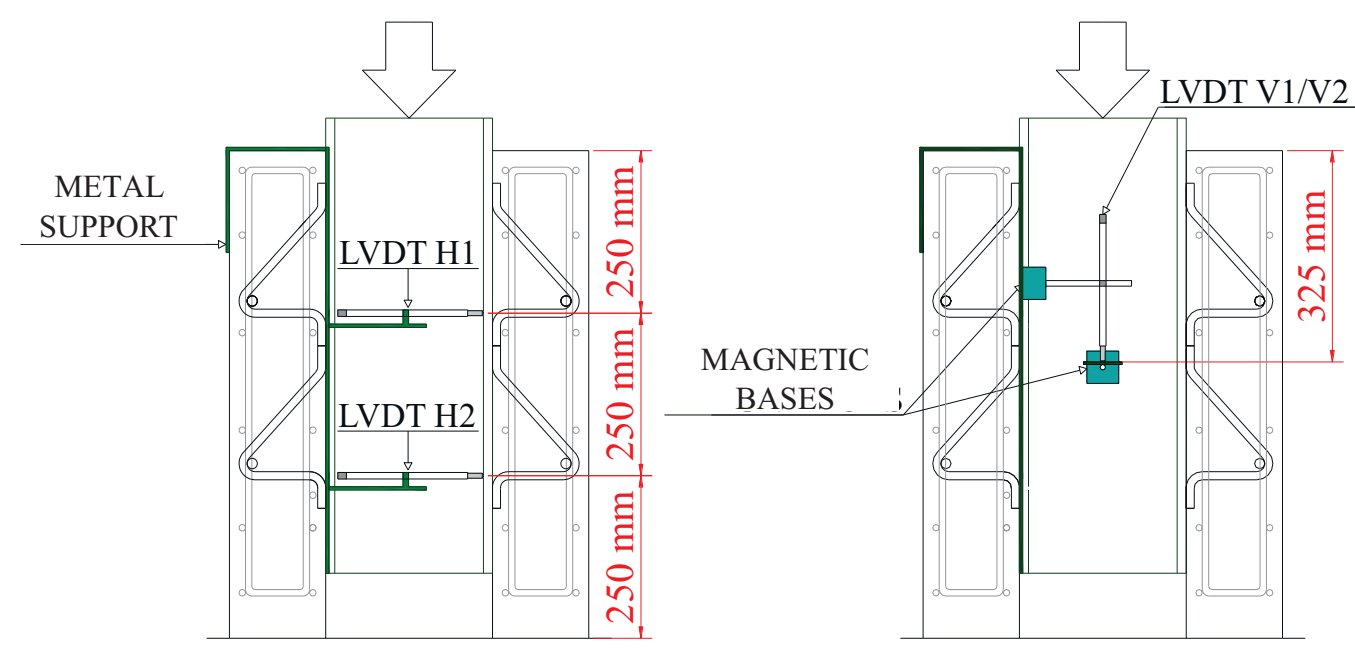

\section{Figure 6}

Positioning of LVDTs

placement of the steel reinforcement and shear connectors. In regards to Eurocode 4 [9], it should be noted that the length of the concrete slabs was increased by $10 \mathrm{~cm}$ just to accommodate the whole extension of the shear connectors.

\subsubsection{Vertical and horizontal displacements}

The vertical displacements of slabs in relationship to the steel profile and the transversal spacings between slabs were monitored through LVDTs (Linear Variable Differential Transformers). The LVDTs were positioned in accordance with Figure 6. Two were placed horizontally for measuring the uplift, and two vertically for the monitoring of the displacements of the steel beams in relation to the concrete slabs. The horizontal LVDTs were fixed with the help of clamps and magnetic bases, while the vertical ones were put in place only using
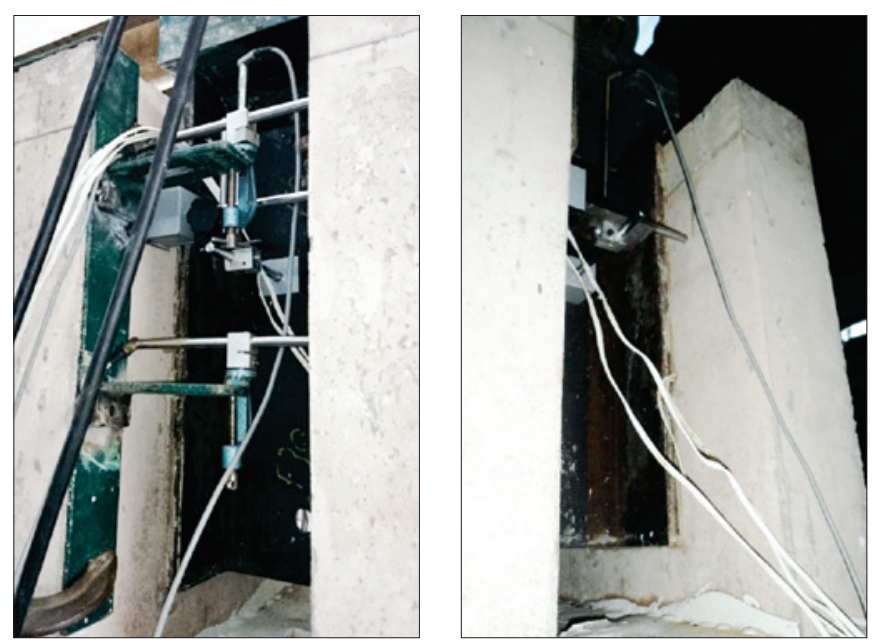

\section{Figure 7}

Positioning of horizontal and vertical LVDTs for the push-out tests the magnetic bases. The points of the two vertical LVDTs touched steel sheets fixed to magnetic bases, which were in turn fixed to the steel profiles of the models, and the points of the horizontal LVDTs were put in direct contact with the surface of the concrete slabs in a position perpendicular to the vertical axis of the specimens.

The horizontal LVDTs were placed at the height of the upper vertices of the connectors, the higher one at a distance of $25 \mathrm{~cm}$ from the upper extreme of the slabs and the lower one $25 \mathrm{~cm}$ lower than the higher one's axis. The vertical LVDTs were placed to measure the vertical displacement of the steel profile in relation to the slabs, at a distance of $325 \mathrm{~mm}$ from the upper extreme of the slabs of each model. Figure 7 presents details of the positioning of the LVDTs in the experimental specimens.

\subsubsection{Loads}

The loads were applied to the steel profiles of the experimental specimens and transmitted to the slabs through the shear connectors. The values of the loads applied to the specimens were obtained through a Load Cell positioned in line with and above the Hydraulic Actuator. The applied loads were registered manually for all the load steps applied and then related to the values of vertical displacements (slide) and uplift for each model tested.

\subsubsection{Test assembly}

The test frame of the Structural Engineering Laboratory in the Civil Engineering Department of the University of Brasilia has a load capacity compatible with the push-out experiments. This frame, which is shared with other research projects, is 3.55 meters high, while the models are 80 centimeters tall. To enable the application of the loads to the specimens, concrete blocks were piled on top of each other, with a plaster layer between them, to promote an even contact between the surfaces and correction of eventual level differences (Cavalcante, 2010 [1]). A steel plate was placed over the last block, and the specimen to be tested set on the steel 


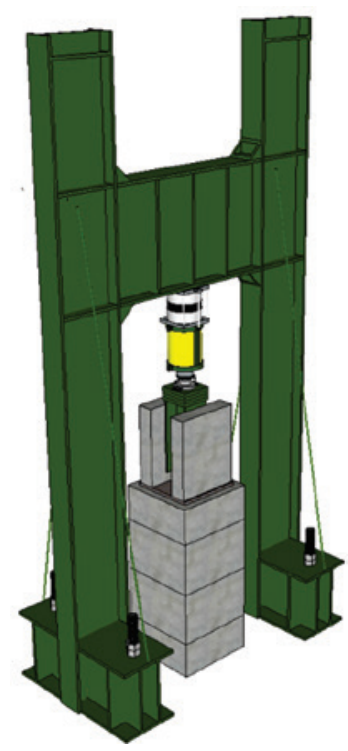

(a) perspective view

\section{Figure 8}

Test assembly for the push-out models

plate, with both being set over plaster layers for the same reasons mentioned before.

Chains were employed surrounding the slabs of the specimens to preventing the falling of concrete slabs or large pieces of concrete debris at the moment of failure. Figure 8 presents details of the test system utilized, with the positioning of the specimens, the Hydraulic Actuator and the Load Cell on the reaction frame.

\subsubsection{Data acquisition system}

The displacement values obtained through the LVDTs were registered for each load step, with the help of Spyder-8 Data Acquisition Modules and the Data Acquisition Software Catman Version 4.5. manufactured by the German company HBM (Hottinger Baldwin Messtechnik $\mathrm{GmbH}$ ). The data was stored in the computer shown in Figure 9 (a), which also displays the Spyder-8 modules. Of the modules displayed in the picture, the one with eight channels was used for the 4 LVDTs employed in each test.

The load data acquisition was accomplished through direct reading of the values of a digital panel and manual annotation; values of loads at the failure and immediately afterward were registered through filming for all the push-out tests. The panel presents values of loads obtained through the Load Cell to which it is connected, with a load display of up to $2000 \mathrm{kN}$. The Load Cell was positioned in between the Hydraulic Actuator, which transmits the loads to the specimens, and the beam of the test steel frame, which offers the reaction to the force applied by the actuator. Figure 9 (b) details this assembly.

The loading was applied through an Electrical Hydraulic Pump shown in Figure 9 (b). This pump allows the application of the load with management of the force, which is displayed on the digital panel.

\section{Results and discussions}

\subsection{Push-out Tests}

Specimens built with Stud Bolt and Truss connector made of bent $12.5 \mathrm{~mm}$ diameter rebars were subjected to push-out experimental tests, with the intention of evaluating the potential of the Truss Connectors proposed in this work and establishing comparative analyses of the displacement results with the Stud Bolt Connector specimens.

The push-out tests were conducted considering the procedures

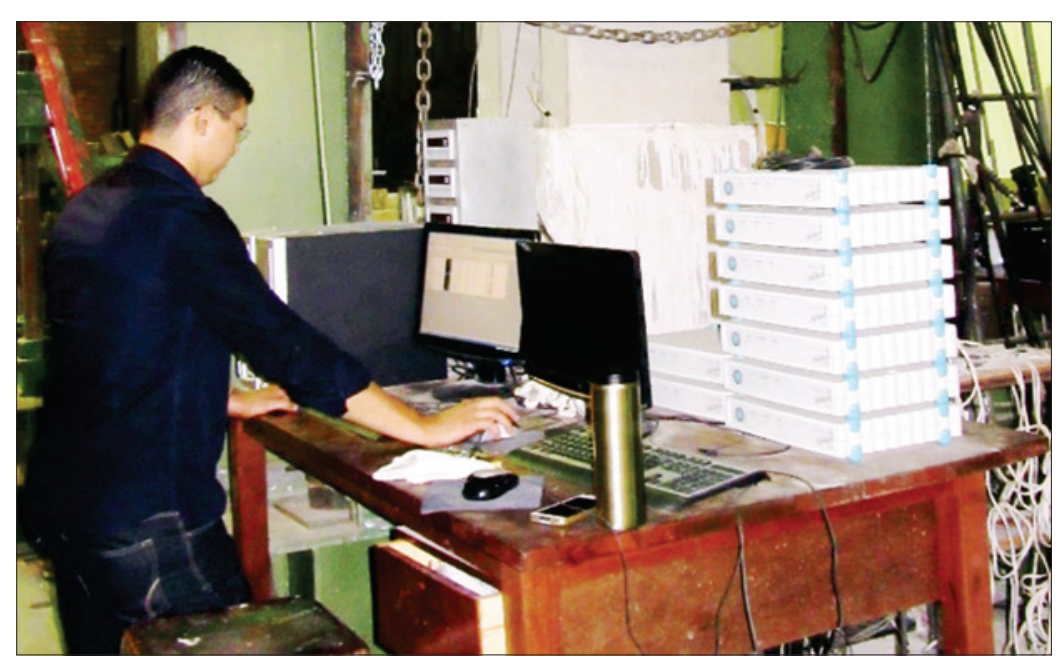

(a)

Data acquisition system

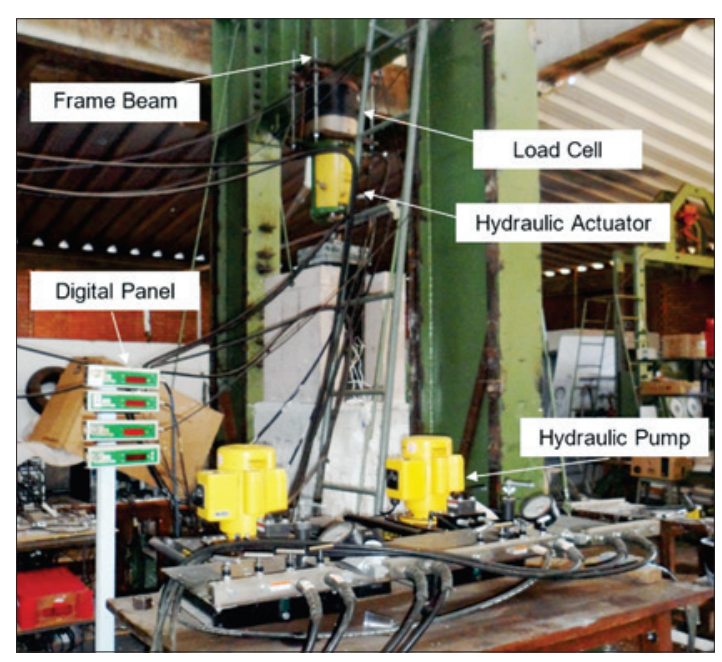

(b)

Testing system

\section{Figure 9}

Data acquisition system and hydraulic pumps for applying loads 
detailed in Eurocode 4 [9], accepted as an international standard for the evaluation of new shear connectors for composite beams in a low cost, fast and reliable way.

The results of the push-out tests obtained for the experimental specimens built are presented next.

\subsubsection{Failure loads and design strength}

The load was applied to the experimental specimens through a

Load application: Specimen S19-1

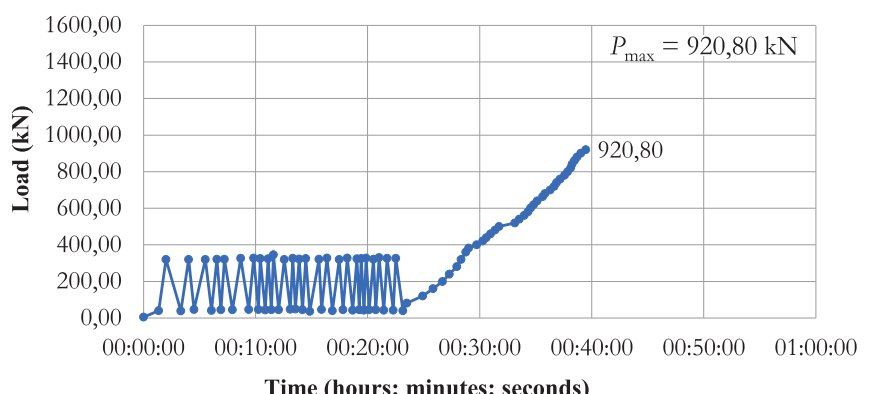

(a)

Specimen 1 - Stud bolt connector

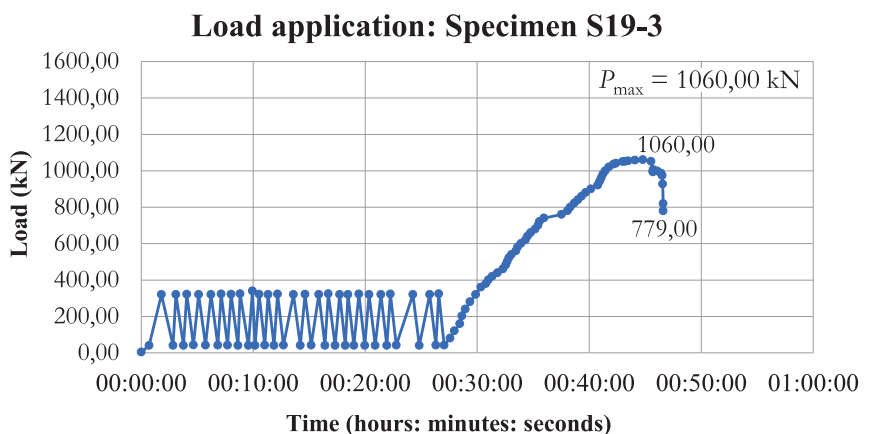

(c)

Specimen 3 - Stud bolt connector

Load application: Specimen R12,5-2

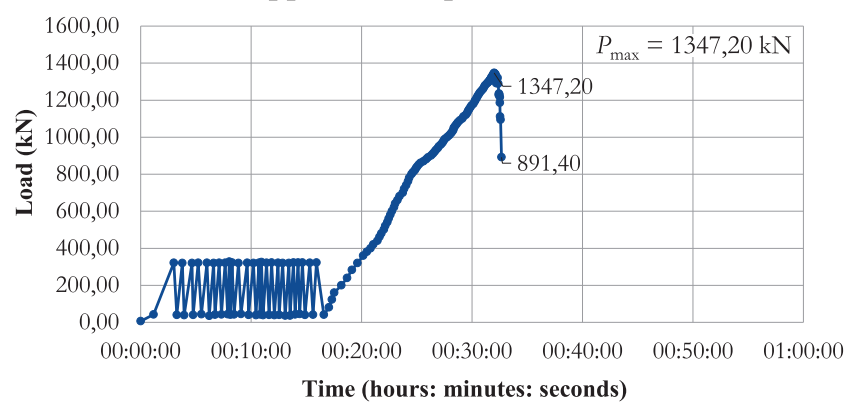

(d)

Specimen 2 - Truss connector $\phi 12.5 \mathrm{~mm}$
Hydraulic Actuator, connected to a Hydraulic Pump and positioned in line with a Load Cell, in accordance with the recommendations of Eurocode 4 [9]. Initially 25 cycles of loading were applied to the specimens, with loads varying from 40 to $320 \mathrm{kN}$ for all specimens, which represents $5 \%$ to $40 \%$ of the estimated failure load for the experimental specimens tested, which was $800 \mathrm{kN}$ for both Truss and Stud Bolt Connectors. Those loads were obtained through numerical studies carried out with the ANSYS Version 14.5 software. Figure 10 presents details of the load application on the specimens

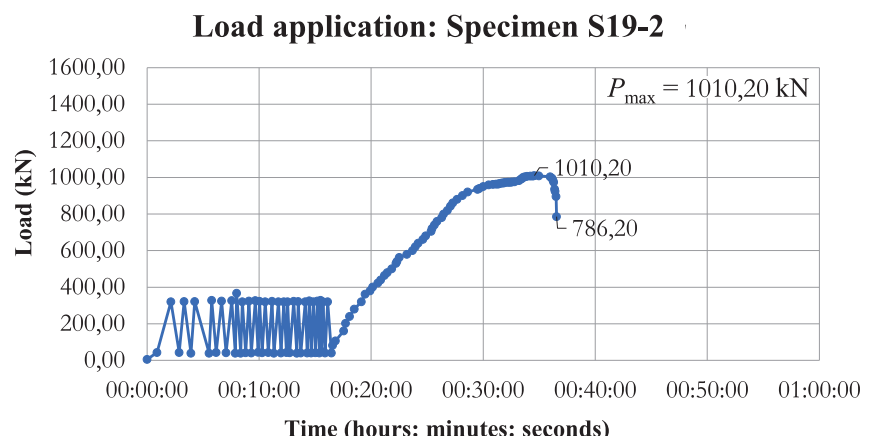

(b)

Specimen 2 - Stud bolt connector

Load application: Specimen R12,5-1

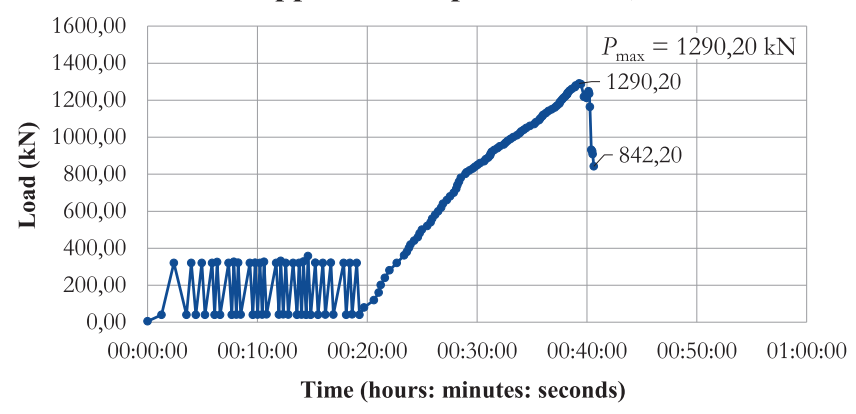

(d)

Specimen 1 - Truss connector $\phi 12.5$ mm

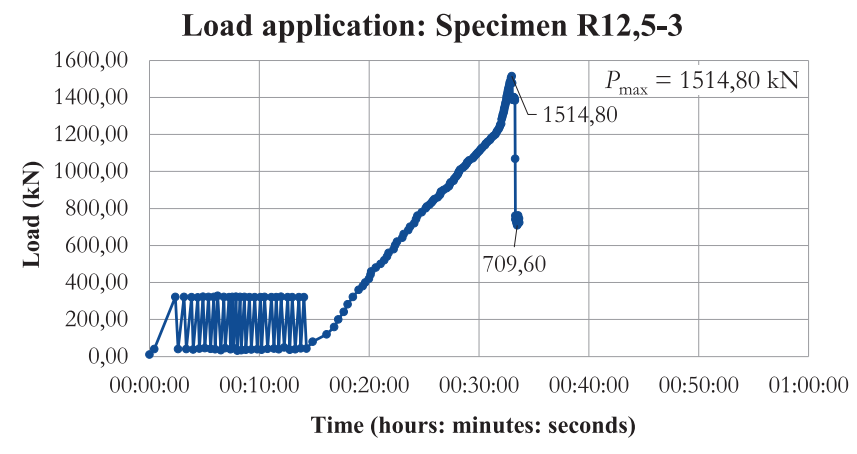

(d)

Specimen 3 - Truss connector $\phi 12.5 \mathrm{~mm}$

Figure 10

Loads versus time results for stud bolts and truss connectors tested 
Table 5

Failure loads for all specimens tested

\begin{tabular}{|c|c|c|c|c|c|}
\hline $\begin{array}{c}\text { Names of } \\
\text { the specimens }\end{array}$ & $\begin{array}{l}P_{\max } \text { total } \\
(\mathrm{kN})\end{array}$ & $\begin{array}{l}P_{\text {med }} \text { total } \\
(\mathrm{kN})\end{array}$ & $\begin{array}{c}P_{\text {cmax }} \begin{array}{l}\text { connector } \\
(\mathrm{kN})\end{array} \\
\end{array}$ & $\begin{array}{c}P_{\text {cmed }} \text { connector } \\
(\mathrm{kN})\end{array}$ & $\begin{array}{c}P_{d} \\
(k N)\end{array}$ \\
\hline SR19-1 & 920.80 & & 115.10 & & \\
\hline SR19-2 & 1010.20 & 997.00 & 126.28 & 124.63 & 58.79 \\
\hline SR19-3 & 1060.00 & & 132.50 & & \\
\hline R12,5-1 & 1290.20 & & 161.28 & & \\
\hline R12,5-2 & 1347.20 & 1384.07 & 168.40 & 173.01 & 87.50 \\
\hline R12,5-3 & 1514.80 & & 189.35 & & \\
\hline
\end{tabular}

throughout the test, with $\mathrm{P}_{\max }$ being the maximum load reached for each specimen tested.

In accordance with Eurocode 4 [9] the experimental specimens must be taken to failure after the $25^{\text {th }}$ loading cycle within a timeframe not inferior to 15 minutes, from the load of $40 \%$ of the estimated failure load $(320 \mathrm{kN})$ and that was accomplished for all six experimental push-out tests. The monitoring of the displacement values was not possible for the phase of unloading $20 \%$ of the maximum load for specimen S19-1, with Stud Bolt Connectors, as may be observed in Figure $10(a)$, because the failure for this specimen was instantaneous, with a sudden fall of the acting load.

Table 5 presents the failure load values for all the specimens tested. The failure loads obtained for the six tests were higher than the estimated $800 \mathrm{kN}$ for the connector configuration employed. The tests were considered valid, with no need to perform additional ones. This validation is in accordance with Eurocode 4 [9] which requires that the three maximum loads $P_{\max }$ should not differ in more than $10 \%$ compared to the mean of the results for specimens with an identical design.

The European Standard Eurocode 4 [9] presents an expression, Equation 1, for the calculation of the design strength of the shear connectors tested through push-out tests.

$P_{R d}=\frac{f_{u}}{f_{u t}} \frac{P_{R k}}{\gamma_{v}} \leq \frac{P_{R k}}{\gamma_{v}}$

where:

$\mathrm{f}_{\mathrm{u}}$ is the minimum failure strength capacity of the connector material; $f_{u t}$ is the actual failure strength of the connector material;

$\mathrm{P}_{\mathrm{Rk}}$ is the minimum failure load of the tested models, divided by the number of connectors, reduced by $10 \%$;

$\gamma_{v}$ is the partial safety factor recommended to be 1.25 by the Eurocode 4 [9].

The design strength obtained through Equation 1 is for one shear connector. Using that equation, the values obtained for the design strength of the Stud Bolt Connector was $58.79 \mathrm{kN}$ and for the Truss Connector with $12.5 \mathrm{~mm}$ diameter was $87.50 \mathrm{kN}$. Each push-out specimen was tested with eight connectors, so the design strength for the models with Stud Bolt Connectors was $470.32 \mathrm{kN}$, and for the specimens with Truss Connectors, $700 \mathrm{kN}$.

As was observed in Cavalcante (2010) [1], the failure of the Stud Bolt Connectors occurred on the metal base close to the welding region, without failure of the welding however, as determined by

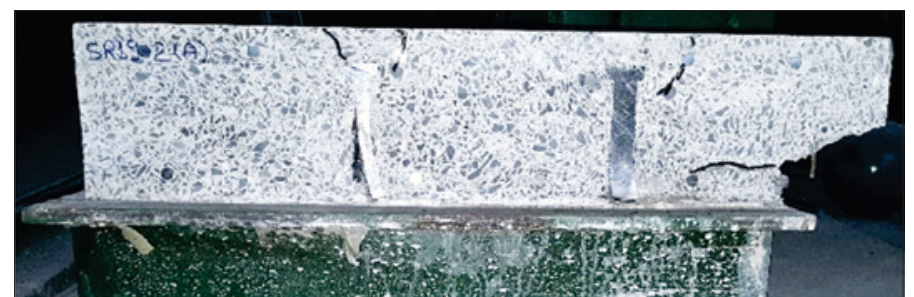

(a)

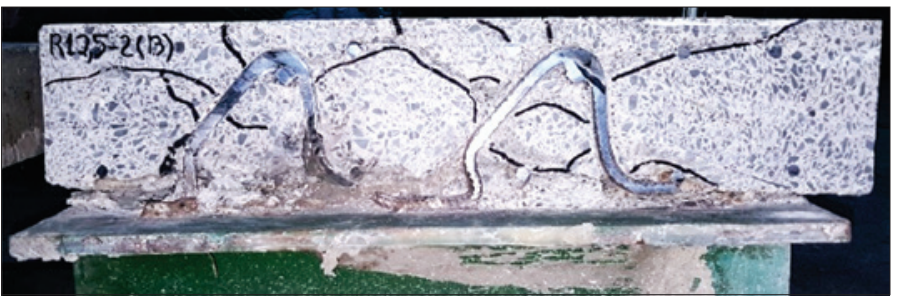

(b)

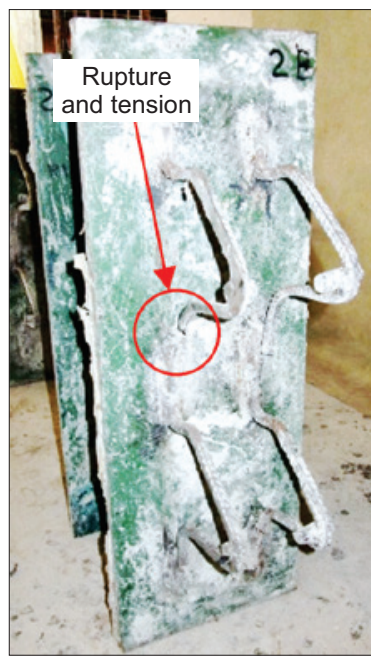

(c)

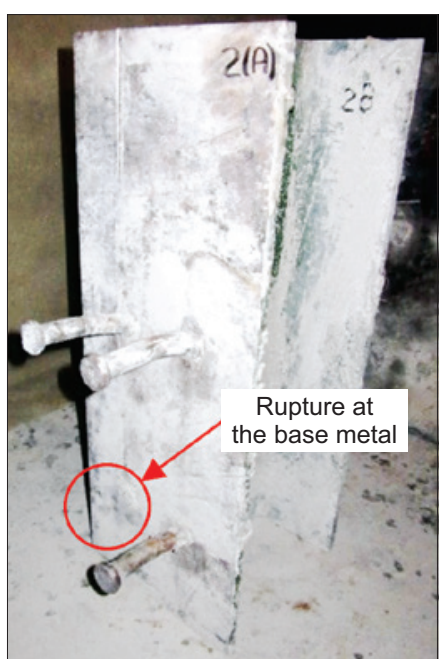

(d)

Figure 11

Analyses of the specimens after failure: (a) Typical longitudinal section of slab A of the S19-2 connector; (b) Typical longitudinal section of slab B of the R12.5-2 connector; (c) Specimen R12.5: Slab-B after concrete demolition; (d) Specimen S19-2: Slab-A after concrete demolition 


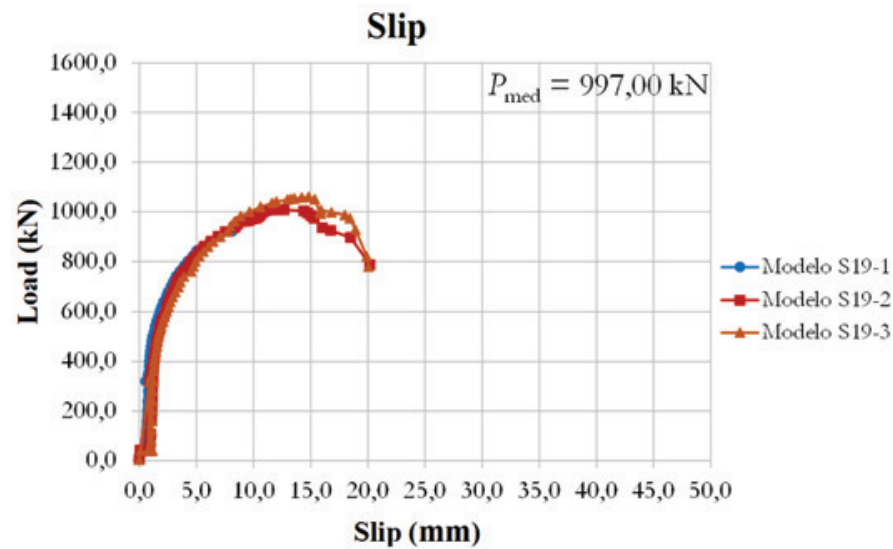

(a)

Stud bolt connectors

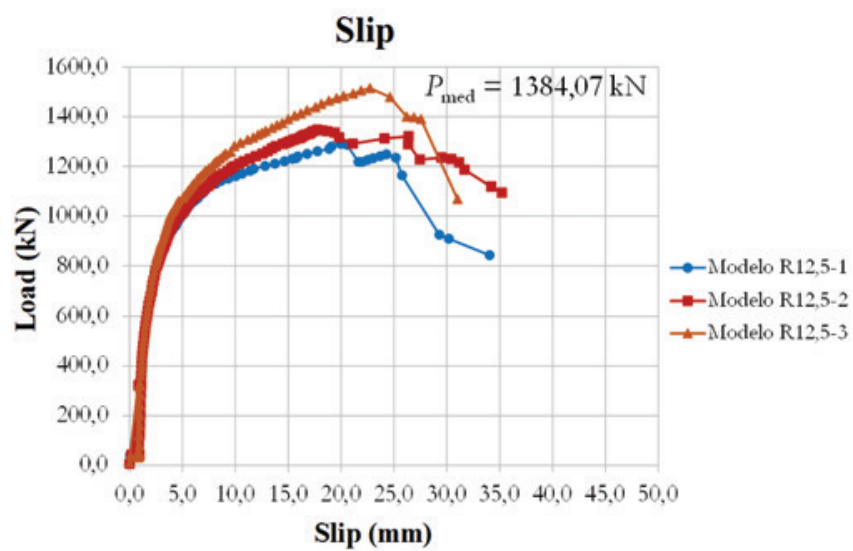

(b)

Truss connectors $\phi 12.5 \mathrm{~mm}$

Figure 12

Average curves: vertical displacement vs applied load - for the specimens tested

AWS D1.1/D1.1M (2015) [14], with the separation of one of the slabs for each specimen tested. For the Truss Connectors, no failure of the welding was observed. The failure of the Truss Connectors happened through tension in one of the legs of the Truss Connectors, with no separation of the slabs from the rest of the model. The cohesion of the parts of the specimens (slabs and steel profiles) was assured by one of the legs of each Truss Connector, which remained complete after the experimental tests. In Truss Connectors, the failures took place in the vertical legs, in the region close to the shearing plane between the concrete slab and the flange of the steel profiles. Figure 11 presents details of the failure modes observed in the experimental models.

\subsubsection{Vertical displacement}

The vertical displacements (slip) between the steel profile and the concrete slabs of the specimens were monitored throughout the push-out tests through two LVDTs positioned symmetrically in relation to the steel profile's web. These LVDTs were named LVDT V1 and LVDT V2. The vertical displacements recorded by the LVDTs $\mathrm{V} 1$ and $\mathrm{V} 2$ are presented in Figure 12.

An analysis of the data of vertical displacements between steel profile and concrete slab was made to classify the connectors in regard to their ductility. Such classification is done considering the load $x$ displacement curves and measuring the displacements (slip) for the unloading of $20 \%$ of the failure load, but such displacement is only measured after failure. The procedure consists of obtaining the characteristic resisting load $\mathrm{P}_{\mathrm{uk}}, 10 \%$ lower than the maximum load achieved and its corresponding vertical displacement (slip) $\left(\delta_{u}\right)$ obtained from the graph. According to Eurocode 4 [9], connectors that present characteristic displacement $\left(\delta_{\mathrm{uk}}=0.9 . \delta_{\mathrm{u}}\right)$ higher than $6.0 \mathrm{~mm}$ in the push-out tests are classified as non-ductile.

Both the Stud Bolt and the Truss Connectors presented $\delta_{\mathrm{uk}}$ values higher than $6.0 \mathrm{~mm}$ and may be classified, therefore, as ductile. According to Eurocode 4 [9], ductile connectors with ideal plastic behavior, with plastic deformation, and good stress distribution in between connectors for service loads may be considered, in the design process. Figure 13 shows $\delta_{u}$ and $\delta_{80}$ values, obtained, respectively, for $90 \%$ and $80 \%$ of the failure loads of each specimen. Table 6 presents the calculated values of $\delta_{\mathrm{uk}}$ and the classification of the connectors with respect to their ductility, in accordance with Eurocode 4 [9] criteria.

\subsubsection{Transversal separation - uplift}

For the monitoring of the transversal separation between slabs, the uplift displacement, two LVDTs were fixed to one slab and touching the other slab, at two heights, to allow for the calculation of the

Table 6

Classification of connectors according to their ductility

\begin{tabular}{|c|c|c|c|c|c|}
\hline $\begin{array}{l}\text { Type of the } \\
\text { connector }\end{array}$ & Model & $\begin{array}{c}\delta_{\mathrm{u}} \\
(\mathrm{mm})\end{array}$ & $\begin{array}{c}\delta_{\mathrm{uk}} \\
(\mathrm{mm})\end{array}$ & $\begin{array}{c}\text { Classification } \\
\text { EN 1994-1-1:2004 [9] }\end{array}$ & Failure mode \\
\hline \multirow{3}{*}{ Stud bolt } & SR19-1 & - & - & - & \multirow{3}{*}{$\begin{array}{l}\text { Rupture at } \\
\text { the base metal }\end{array}$} \\
\hline & SR19-2 & 17.50 & 15.75 & Ductile & \\
\hline & SR19-3 & 18.60 & 16.74 & Ductile & \\
\hline \multirow{3}{*}{$\begin{array}{l}\text { Truss connector with } \\
\qquad 12,5 \mathrm{~mm}\end{array}$} & R12.5-1 & 25.75 & 23.18 & Ductile & \multirow{3}{*}{$\begin{array}{c}\text { Rupture of } \\
\text { connector vertica } \\
\text { leg and concrete }\end{array}$} \\
\hline & R12.5-2 & 27.40 & 24.66 & Ductile & \\
\hline & $\mathrm{R} 12.5-3$ & 27.90 & 25.11 & Ductile & \\
\hline
\end{tabular}




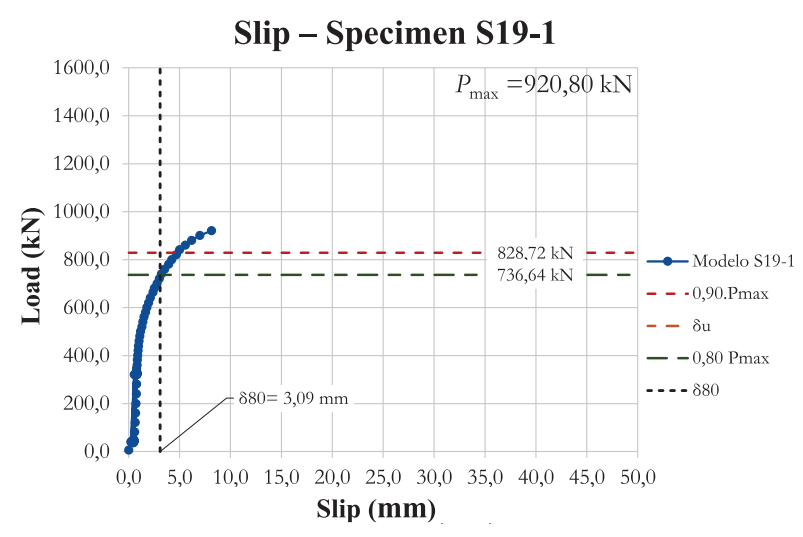

(a)

Specimen 1 - Stud Bolt

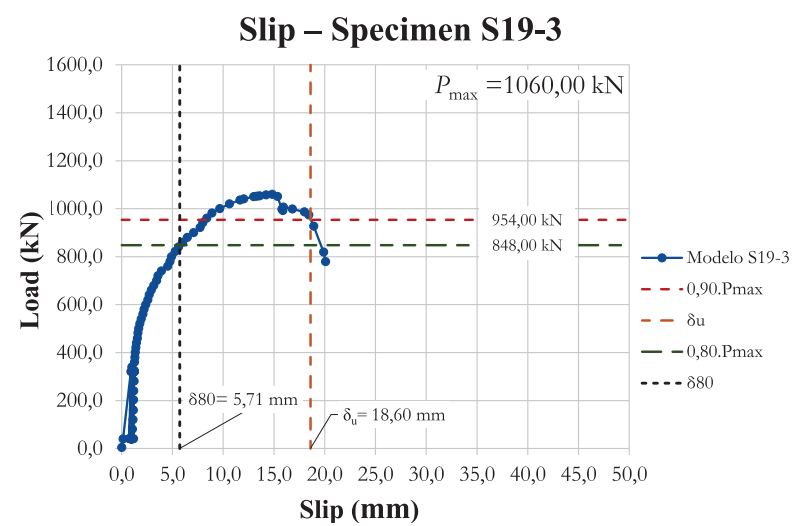

(c)

Model 3 - Stud Boltr

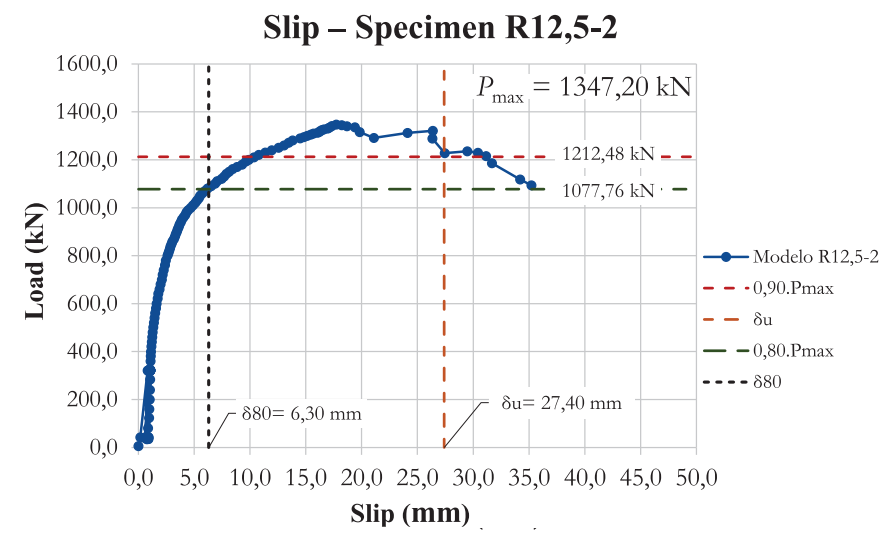

(e)

Model 2 - Truss connector $\phi 12.5 \mathrm{~mm}$

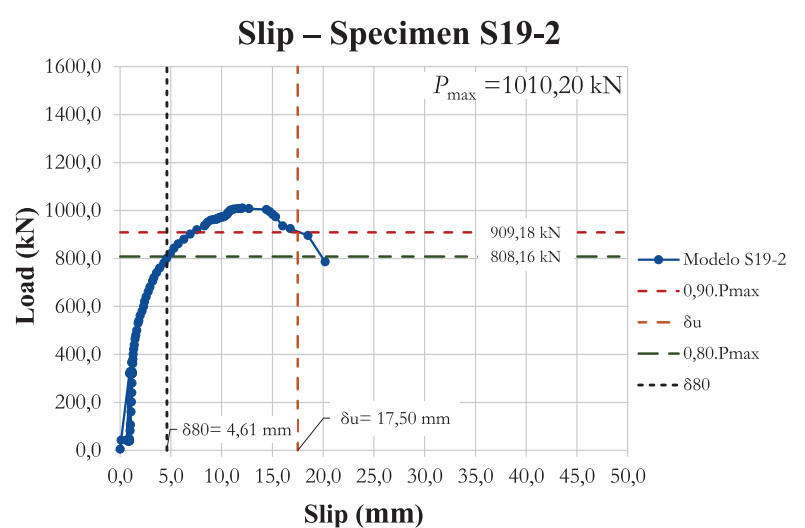

(b)

Model 2 - Stud Bolt

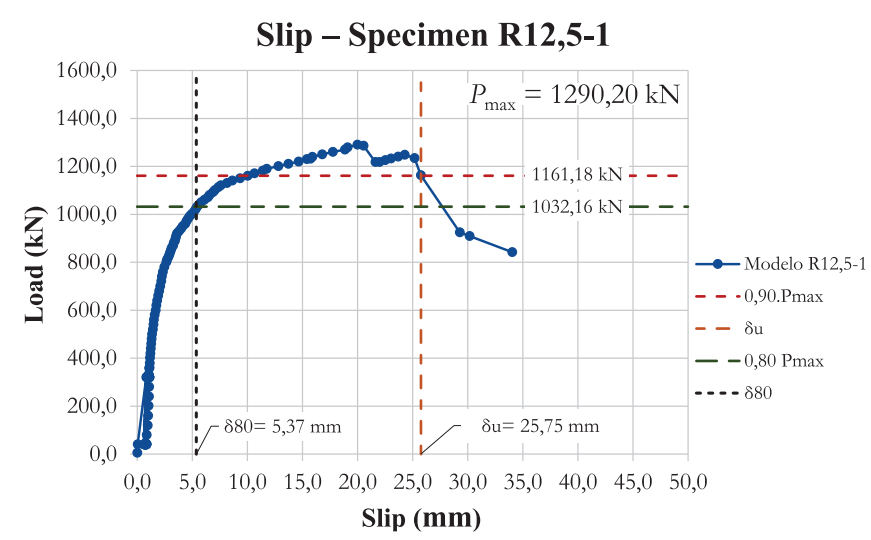

(d)

Specimen 1 - Truss connector $\phi 12.5 \mathrm{~mm}$

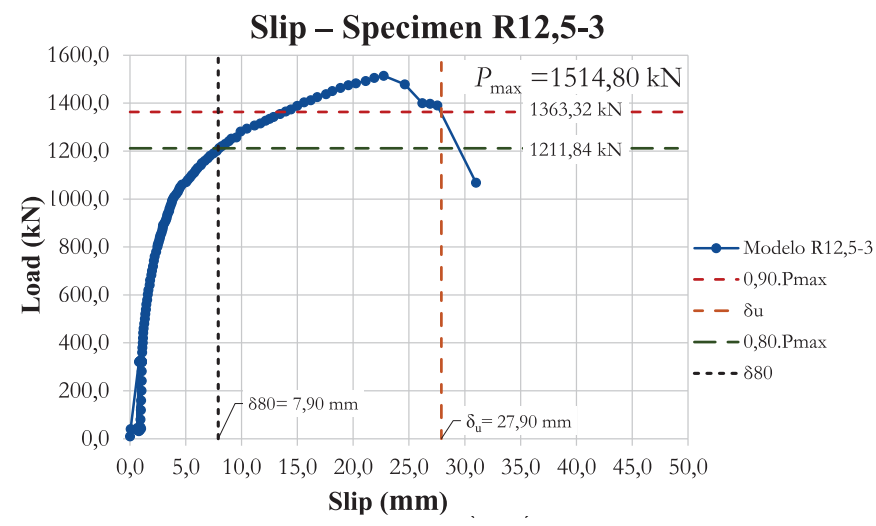

(f)

Model 3 - Truss connector $\phi 12.5 \mathrm{~mm}$

\section{Figure 13}

Average curves: vertical displacement vs applied load for the specimens tested for the calculation of the characteristic vertical-displacements (slip) 


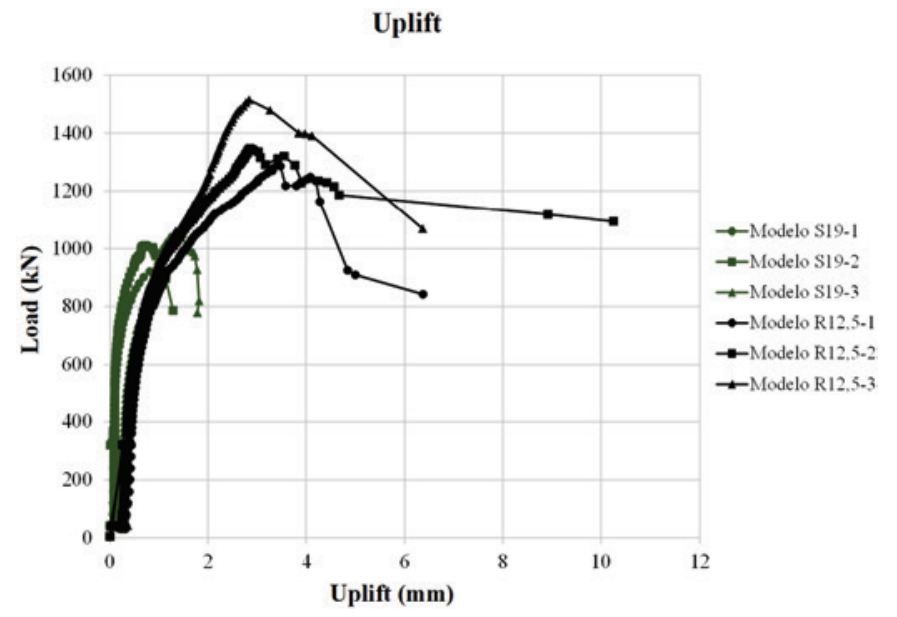

Figure 14

Curves of the average transversal separation (uplift) vs applied load for the push-out tests

average displacement at the position of the centroid of the connectors. Figure 14 compares the average values of both horizontal LVDTs for each specimen tested.

The tests reveal that the LVDTs $\mathrm{H} 1$ and $\mathrm{H} 2$ registered close results for the separation of the slabs as the load increased, which leads to the conclusion that the horizontal separation between slabs happened in a similar way at both positions. For the $12.5 \mathrm{~mm}$ diameter, the uplift for the Truss Connector specimens was higher. This higher uplift was in the lower part of the slabs for loads close to $P_{\text {max }}$ (maximum test load) and the load decline stage at the end of the tests.

Figure 14 shows that Truss Connectors led to greater maximum loads and greater uplifts too, for each experimental specimen. In some structural situations, as in composite beams, besides the longitudinal shear forces, the connectors are also subject to forces perpendicular to the axis of the beam. Such forces tend to cause the separation of the concrete slab and the steel profile. Generally, these transversal forces are much lower than the longitudinal shear forces, and in practical situations, it is not necessary to calculate them.

\section{Conclusion}

The push-out tests carried out in this research in accordance with the procedures established in Eurocode 4 [9] are internationally known, accepted, and largely utilized for the assessment of new types of shear connectors.

The push-out test applied to the proposed Truss Connectors followed the procedures established in Eurocode 4 [9]. The proposed connector, welded to the steel profile flange, is in the shape of a rectangular triangle, and made of CA- 50 steel bar with a 12.5 $\mathrm{mm}$ diameter. The results from the push-out tests compared to the results of Stud Bolt Connectors (19.0 mm diameter) show that the Truss Connector has higher strength capacity. Moreover, the material of such connector is easily found and the fabrication process is widely known. Furthermore, the proposed connector conforms to the slip longitudinal displacement and uplift displacement between slab and steel profile, as specified by Eurocode 4 [9].
The push-out tests were conducted with the intent of characterizing the shear connectors studied as to their design strength capacity and ductility, in accordance with Eurocode 4 [9]. Thus, concerning the experimental tests, the following can be concluded:

- The maximum strength of the push-out specimens with 8 Truss Connectors showed, on average, is $1384.07 \mathrm{kN}$, which corresponds to $173 \mathrm{kN}$ per connector. For the Stud Bolt Connectors the average of the maximum strengths is $997.00 \mathrm{kN}$, resulting in $124.63 \mathrm{kN}$ per connector;

- The design resistance, determined according to the Eurocode 4 [9], resulted in a value of $62.45 \mathrm{kN}$ per connector for the Stud Bolt and $87.50 \mathrm{kN}$ per connector for the Truss Connector with $12.5 \mathrm{~mm}$ diameter rebar;

- The relief of load of $20 \%$ at the end of the tests was carried out for five specimens subjected to push-out tests, 3 of them with the Truss Connectors and 2 with the Stud Bolt. This data allowed the classification of both type of connectors as ductile. For this reason, they showed plastic behavior upon failure and adequate distribution of stresses between connectors for service loads;

- Truss Connectors made of steel bars $12.5 \mathrm{~mm}$ in diameter provide higher strength and higher values of uplift in comparison to Stud Bolt Connectors;

- Upon failure, the Truss Connectors vertical leg tore out due to tension, but welding was kept intact between connectors' legs and the steel profile flange. The failure of the Stud Bolt Connectors was observed at the welding region between connector and the steel profile flange showed rupture of the base metal.

\section{Acknowledgments}

The authors would like to thank the following companies: (a) CONCRECON for the donation of all the concrete used in this research and (b) CPC ESTRUTURAS for the donation of all the steel profiles and Stud Bolt Connectors employed during the push-out tests. The authors also want to express their gratitude to (1) CPNQ (The Brazilian National Council for Scientific and Technological Development), (2) CAPES (Coordination for the Improvement of Higher Level Education), for the research grants. Finally, the authors wish to thank the University of Brasilia (UnB) for the use of its laboratories and facilities.

\section{Bibliographic references}

[1] CAVALCANTE, O. R. O. (2010). Estudo de Conectores de Cisalhamento do Tipo 'V' em Vigas Mistas. Tese de Doutorado em Estruturas e Construção Civil, Publicação E.TD - 006/10, Departamento de Engenharia Civil e Ambiental, Universidade de Brasília, Brasília, DF, 192p.

[2] ASSOCIAÇÃO BRASILEIRA DE NORMAS TÉCNICAS. (2008). ABNT NBR 8800. Projeto e execução de estruturas de aço e de mistas aço e concreto de edifícios.

[3] CHAVES, I. A., (2009). Viga mista de aço e concreto constituída por perfil formado a frio preenchido. Dissertação (Mestrado-Programa de Pós-Graduação e Área de Concentração em Engenharia de Estruturas) - Escola de Engenharia de São Carlos da Universidade de São Paulo, 2009. 
[4] VERÍSSIMO, G. S., (2007). Desenvolvimento de um conector de cisalhamento em chapa dentada para estruturas mistas de aço e concreto e estudo do seu comportamento. Tese de Doutorado em Estruturas, Escola de Engenharia, Universidade de Federal de Minas Gerais, 290p.

[5] REHMAN N., D. LAM, X. DAI, A.F. ASHOUR., (2016). Experimental study on demountable shear connectors in composite slabs with profiled decking. Journal of Constructional Steel Research, 122. pp. 178-189.

[6] DAI X.H., D. LAM, E. SAVERI; (2015). Effect of concrete strength and stud collar size to shear capacity of demountable shear connectors. Journal of Structural Engineering, American Society of Civil Engineers, 141.

[7] PATHIRANA S.W., B. UY, O. MIRZA, X. ZHU., (2015). Strengthening of existing composite steel concrete beams utilizing bolted connectors and welded studs. Journal of Constructional Steel Research, 114. pp. 417-430.

[8] BARBOSA, W. C. S., (2016). Estudo de Conectores de Cisalhamento em Barras de Aço para Vigas Mistas de Aço e Concreto. Tese de Doutorado em Estruturas e Construção Civil, Publicação E.TD - 008A/16, Departamento de Engenharia Civil e Ambiental, Universidade de Brasília, Brasília, DF, 511p.

[9] EUROPEAN COMMITTEE FOR STANDARDIZATION (2004). 1994-1-1: Eurocode 4 - Design of composite steel and concrete structures; Part 1.1: General rules and rules for buildings.

[10] ASSOCIAÇÃO BRASILEIRA DE NORMAS TÉCNICAS. (2007). ABNT NBR 5739. Concreto - Ensaio de compressão de corpos de prova cilíndricos.

[11] ASSOCIAÇÃO BRASILEIRA DE NORMAS TÉCNICAS. (2008). ABNT NBR 8522. Concreto - Determinação do módulo estático de elasticidade à compressão.

[12] ASSOCIAÇÃO BRASILEIRA DE NORMAS TÉCNICAS. (2013). ABNT NBR ISO 6892-1. Materiais metálicos - Ensaio de Tração Parte 1: Método de ensaio à temperatura ambiente.

[13] ASSOCIAÇÃO BRASILEIRA DE NORMAS TÉCNICAS. (2007). ABNT NBR 7480. Aço destinado a armaduras para estruturas de concreto armado - Especificação.

[14] AWS D1.1/D1.1M (2015). Structural Welding Code - Steel. American Welding Society (AWS) D1 Committee on Structural Welding.

[15] JOHNSON, R. P. (1994). Composite Structures of Stell and Concrete - Beams, Slabs, Columns, and Frames for Buildings. Vol. 1, $2^{\text {nd }}$ edition, Oxford (UK): Blackwell Science Ltd. 